\title{
Vegetation Responses to Prescribed Burning of Grazed Shortgrass Steppe
}

\author{
David J. Augustine ${ }^{1}$ and Daniel G. Milchunas ${ }^{2}$
}

Authors are ${ }^{1}$ Research Ecologist, US Department of Agriculture-Agricultural Research Service (USDA-ARS), Rangeland Resources Research Unit, Fort Collins, CO 80526, USA; and ${ }^{2}$ Research Scientist, Forest, Rangeland and Watershed Stewardship Department and Natural Resource Ecology Laboratory, Colorado State University, Fort Collins, CO, 80523, USA.

\begin{abstract}
Over the past century, fire has been widely suppressed in the western Great Plains, in part because of the potential negative effects on forage production for livestock. More recently, interest in the use of prescribed fire in shortgrass steppe has increased because of the potential applications for wildlife management, control of unpalatable plant species, and restoration of historic disturbance regimes. We studied the effects of prescribed burns conducted during late winter on herbaceous production, forage nitrogen content, and plant species composition of shortgrass steppe on the Pawnee National Grassland in northeastern Colorado. Late-winter burns conducted in moderately grazed sites under a wide range of precipitation conditions during 19972001 did not negatively affect herbaceous production in either the first or the second postburn growing season. Burning followed by a severe drought in 2002 reduced production by $19 \%$ in the second postburn growing season of 2003. Burns temporarily suppressed the abundance of broom snakeweed (Gutierrezia sarothrae) and prickly pear cactus (Opuntia polyacantha) and enhanced forage nitrogen content during May and June of the first postburn growing season. These findings suggest that, except following severe drought, prescribed burns conducted during late winter in grazed shortgrass steppe for objectives unrelated to livestock production can also have neutral or positive consequences for livestock.
\end{abstract}

\section{Resumen}

Durante el último siglo, el fuego ha sido ampliamente excluido en las grandes planicies del oeste de los Estados Unidos, en parte debido a los efectos negativos potenciales en la producción de forraje para el ganado. Más recientemente, el interés en el uso de las quemas prescritas en los pastizales cortos ha aumentado por razón del uso potencial para el manejo de la fauna silvestre, control de las plantas no deseables y la recuperación de los regímenes históricos de disturbios. Se estudió el efecto de las quemas prescritas hechas al final del invierno en la producción de herbáceas, contenido de nitrógeno del forraje y la composición de especies en un pastizal corto en el Noreste del estado de Colorado, en los pastizales nacionales de Pawnee. Las quemas efectuadas al final del invierno en sitios moderadamente pastoreados, bajo un amplio rango de condiciones de precipitación durante 1997-2001 no afectaron negativamente la producción de forraje tanto en la primera como en la segunda época de crecimiento después de la quema. La quema seguida de una sequia severa durante 2002 redujo la producción alrededor de $19 \%$ en la segunda época de crecimiento después de la quema durante 2003. Las quemas controlaron temporalmente la abundancia de la escobilla (Gutierrezia sarothrae) y el nopal (Opuntia polyacantha), e incrementaron el contenido de nitrógeno del forraje durante los meses de mayo y junio después de la quema durante la primera época de crecimiento. Estos resultados sugieren que con la excepción de una sequía severa después de la quema, que las quemas prescritas que se hacen al final del invierno en pastizales cortos, con objetivos no relacionados con la producción ganadera, pueden también traer consecuencias neutrales o positivas para el ganado.

Key Words: Bouteloua gracilis, fire-grazing interaction, forage quality, Gutierrezia sarothrae, mountain plover, Opuntia polyacantha

\section{INTRODUCTION}

Fire and grazing are key disturbance processes that influence the structure and function of rangeland ecosystems. In the Great Plains of central North America, fire has long been recognized as an important component of the disturbance regime (Wright and Bailey 1982), but its use in combination with grazing management varies considerably across the

Research was funded by the Shortgrass Steppe Long Term Ecological Research Program (NSF DEB-0217631), USDA-Forest Service, and USDA-ARS.

The USDA-ARS, Northern Plains Area, is an equal opportunity/affirmative action employer, and all agency services are available without discrimination.

Mention of trade names is for information only and does not imply an endorsement.

Correspondence: David J. Augustine, USDA-ARS, 1701 Centre Ave, Fort Collins, C0 80526, USA. Email: David.Augustine@ars.usda.gov

Manuscript received 22 May 2008; manuscript accepted 17 October 2008. region. In tallgrass prairie, fire is used to remove accumulated dead biomass from pastures prior to the onset of the growing season, and a large body of research has examined the effects of fire and interactions with herbivores in this ecosystem (Wright and Bailey 1982; Knapp et al. 1999; Engle and Bidwell 2001; Fuhlendorf and Engle 2004; Collins and Smith 2006). Fire has also been acknowledged as an important component of the western, semiarid grasslands of the Great Plains (Wright and Bailey 1982; Brockway et al. 2002; Erichsen-Arychuk et al. 2002). At least one bird species endemic to the western Great Plains is adapted to breed in recent burns (Svingen and Giesen 1999; Knopf and Wunder 2006), and one widespread sagebrush species in the western Great Plains resprouts rapidly after burns (Vermiere et al. 2001). However, several early studies of fires in this region observed negative effects on forage production (Hopkins et al. 1948; Launchbaugh 1964; Dwyer and Pieper 1967), leading to the conclusion that "generally, fire 
is not used in the shortgrass prairie because it seldom enhances the growth of grasses" (Wright and Bailey 1982, p. 404).

These early studies were based on comparisons of unplanned wildfires to adjacent unburned grassland. Like grazing, the effect of fires on grassland dynamics can depend on a host of factors, including fire intensity, timing relative to precipitation and plant growth, fire frequency, plant community composition, and topography (Engle and Bidwell 2001). Based on reviews of early studies of fire effects in shortgrass steppe, two hypotheses have been advanced concerning determinants of fire effects on plant production. The first is season of burning, where burns that occur under warmer conditions and when a portion of the vegetation is still photosynthetically active are more detrimental to subsequent plant growth than burns occurring under cooler conditions and in dormant vegetation (Wright and Bailey 1982; Ford 1999). The second is soil moisture availability during the first growing season after the burn, where burns followed by dry conditions will have the strongest negative effects on plant production (Wright and Bailey 1982; Ford 1999). One potential mechanism is that in semiarid regions where much of the precipitation in dry years occurs in small events (Sala and Lauenroth 1982), loss of litter on burned sites may result in greater evaporative moisture loss compared to unburned sites. The fact that most early studies in shortgrass steppe examined wildfires under dry conditions has limited our ability to evaluate these hypotheses (Ford 1999).

Use of prescribed burning in shortgrass steppe of the western Great Plains has increased because of interest in restoring historic disturbance regimes (Brockway et al. 2002) and applications for wildlife habitat management (Svingen and Giesen 1999; Augustine et al. 2007; Thompson et al. 2008). Prescribed burning also has the potential to suppress unpalatable plant species that reduce the production or accessibility of palatable forage, in particular broom snakeweed (Gutierrezia sarothrae; McDaniel et al. 1997) and prickly pear cactus (Opuntia polyacantha; Bement 1968; Rebollo et al. 2002). Furthermore, burning can be used to manipulate the distribution of large ruminant herbivores by enhancing forage quality in tallgrass prairie (Coppedge and Shaw 1998; Fuhlendorf and Engle 2004; Vermiere et al. 2004), but effects of burning on forage quality in shortgrass steppe have rarely been considered (Brockway et al. 2002).

On National Grasslands within the shortgrass steppe, multiple-use management by the US Department of Agriculture (USDA)-Forest Service seeks to provide forage for permitted livestock while maintaining native biodiversity. Over the past decade, prescribed burning programs on these National Grasslands have been developed in part to provide nesting habitat for the mountain plover (Charadrius montanus), a grassland bird native to the western Great Plains whose populations have declined over the past several decades (Knopf and Wunder 2006). Prescribed burns are typically conducted in late winter prior to the initiation of plant growth and the arrival of mountain plovers from their winter range. One concern for livestock producers is the effect that such burns have on forage production. Recent experiments on the Kiowa National Grassland found that growing-season burns substantially reduced forage production $(66 \%)$ and that dormant-season burns reduced production to a lesser extent $(33 \%)$ during the first postburn growing season (Brockway et al. 2002). A subsequent study at this site found significant reductions in perennial grass cover by growing-season fires but no significant effect of dormant-season fires (Ford and Johnson 2006). However, both studies were conducted in ungrazed grassland.

Here, we report on a 6-yr study of fire effects on grazed shortgrass steppe on the Pawnee National Grassland in northeastern Colorado. We examined the effects of prescribed burns conducted during late winter (March) in grassland grazed by cattle during May-October each year. Our primary objectives were to evaluate 1) whether prescribed burning affects aboveground net herbaceous production (ANHP); 2) whether the effects are dependent on interannual variability in precipitation; 3) whether prescribed burns suppress the abundance of two unpalatable plants, broom snakeweed (G. sarothrae) and prickly pear cactus (O. polyacantha); and 4) whether burning increases the nitrogen content in forage available to large herbivores.

\section{METHODS}

The study area was the western unit of the Pawnee National Grassland, located approximately $40 \mathrm{~km}$ northeast of Greeley in Weld County, Colorado. The climate is semiarid, with cold, dry winters; most precipitation falls as rain between April and September (Lauenroth and Milchunas 1992). Long-term mean annual precipitation measured at the western edge of the study area is $344 \mathrm{~mm}$ (1940-2005). Vegetation is dominated by the perennial, grazing-tolerant shortgrasses, blue grama (Bouteloua gracilis) and buffalograss (Buchloe dactyloides; Milchunas et al. 1989; Lauenroth and Milchunas 1992). Prickly pear cactus is also an important species in terms of basal cover (Milchunas et al. 1989) and creates local refugia from grazing (Rebollo et al. 2005). Broom snakeweed is one of the three most abundant subshrub species and is widely distributed at low to moderate densities in the region (Milchunas et al. 2008).

We studied prescribed burns conducted by the USDA-Forest Service during 1997-2002 (Table 1). In all years except 1999, we studied a single 259-ha burn. For each 259-ha burn, we established four replicate burned and adjacent unburned (control) sampling sites paired based on similar topography and soils, with pairs unfenced between burn and control to ensure the same potential for cattle access and the same history of livestock grazing. An exception was in 1997, when only three burned and control sites could be paired. In 1999, we studied four replicate 65 -ha burns conducted in four different allotments. In this year, we sampled one burned site and one paired control site at each allotment. The burns in 1998 and 2002 were conducted at the same location; we studied the responses in 2002 to gain insight into the effects of burning the same location twice within a 4-yr period. However, the measurements from these two burns are not independent and were treated accordingly in statistical analyses. To quantify variation in growing-season precipitation among years, we used April-July precipitation because 1) amounts falling in winter are minimal and much sublimes, 2) spring precipitation explains much of the annual ANHP in this study area (Milchunas et al. 1994), and 3) biomass measurements were in August.

Allotments on the Pawnee National Grassland are managed to achieve a targeted residual biomass of $336 \mathrm{~kg} \cdot \mathrm{ha}^{-1}$ and are 
Table 1. Summary of five prescribed burning studies conducted in shortgrass steppe on the Pawnee National Grassland, Colorado.

\begin{tabular}{ccccccc}
\hline Experiment & $\begin{array}{c}\text { Burn } \\
\text { year(s) }\end{array}$ & $\begin{array}{c}\text { No. of } \\
\text { burns }\end{array}$ & $\begin{array}{c}\text { Size of } \\
\text { burn(s) (ha) }\end{array}$ & $\begin{array}{c}\text { April-July precipitation } \\
\text { in burn year }(\mathrm{mm})\end{array}$ & $\begin{array}{c}\text { Years of postburn ANHP } \\
\text { measurements }{ }^{1}\end{array}$ & Unpalatable species measured \\
\hline 1 & 1997 & 1 & 259 & 275 & 2 & - \\
2 & 1998,2002 & 1 & 259 & 161,92 & 1,2 & Opuntia polyacantha; Gutierrezia sarothrae \\
3 & 1999 & 4 & 65 & 345 & 2 & G. sarothrae \\
4 & 2000 & 1 & 259 & 98 & 1 & 0. polyacantha \\
5 & 2001 & 1 & 259 & 207 & 2 & 0. polyacantha \\
\hline
\end{tabular}

${ }^{1} \mathrm{ANHP}$ indicates aboveground net herbaceous production.

grazed during May 15-October 15. Stocking rates in the allotments we studied were $0.63-0.75$ animal unit months (AUM) $\cdot \mathrm{ha}^{-1}$, except during the drought in 2002, when rates were reduced to $0.17-0.18 \mathrm{AUM} \cdot \mathrm{ha}^{-1}$. Burns were conducted in February or March, when fine fuel moisture content was minimal and plants had not yet initiated growth. Burns during 1999-2002 were implemented with mean air temperatures of $6-14{ }^{\circ} \mathrm{C}$, relative humidity of $20-35 \%$, and wind speeds of $1.9-$ $6.6 \mathrm{~m} \cdot \mathrm{s}^{-1}$ (weather conditions not available for 1997-1998). Flame lengths were typically less than $1 \mathrm{~m}$. Burned sites we studied were affected by headfires that moved rapidly across the site, resulting in relatively complete and homogeneous consumption of fuels.

At each burned and control sampling site, we randomly established five $1-\mathrm{m}^{2}$ grazing exclusion cages within a $50 \times 50 \mathrm{~m}$ area in spring prior to the grazing season. We then harvested all plant biomass above crown height within a $0.25-\mathrm{m}^{2}$ quadrat in each grazing cage in early August. Harvests were sorted by species and by tissue produced in the current year (live plus recent dead and current-year growth of perennial subshrubs) versus previous growing seasons (old-standing dead); litter was collected separately. Harvests were in early August to best estimate peak standing crop for the current growing season, which provides the least biased estimate of ANHP in this dominantly warm-season community with a short growing season (Milchunas and Lauenroth 1992). We calculated ANHP as the sum of peak standing crop for all grasses, forbs, and subshrubs (i.e., excluding cactus and perennial shrubs). Nitrogen content of current-year growth of biomass harvested in August was measured after compositing biomass for the two dominant grasses (blue grama and buffalograss). When possible, ANHP was measured again using the same methods during the second postburn growing season (Table 1) after randomly moving cages from the clip locations used for the first postburn growing season measurements.

Pluck samples of blue grama and the dominant forb species (scarlet globemallow Sphaeralcea coccinia) were collected for nitrogen analyses in mid-May, mid-June, and mid-July of the first postburn growing season for burns conducted during 1999-2002. Each sample was clipped at a height to represent a "bite" that could be taken by a grazing cow and included all standing tissue. Ten samples were composited from along each of three 50-m transects for each species at each treatment replicate. In 2002, samples were later sorted in the lab into current-year and previous-year growth. The dead potion of the samples were analyzed to determine the degree to which removal of standing dead by the burns affects the nitrogen content of aboveground biomass available to large grazers, while the live portion represented the degree to which the burn may make nitrogen more available through soil processes. Blue grama is a bunchgrass for which new growth in the spring is typically closely intermixed with standing dead biomass retained from the previous growing season; scarlet globemallow is a perennial forb whose growth form typically results in minimal dead material being retained from the previous year.

We measured the effect of prescribed burning on broom snakeweed in 1998, 1999, and 2002 and on plains prickly pear cactus in 2000, 2001, and 2002 (Table 1). For broom snakeweed, we marked 10 individuals in the January preceding the burn along each of three transects in each treatment and replicate. For each individual, we measured the diameter of the widest live portion of the canopy, the diameter perpendicular to the first measurement, and the height. We then remeasured all shrubs in August after the burn and recorded mortality for shrubs that did not resprout during the growing season. For prickly pear cactus, we permanently marked $10 \quad 0.25-\mathrm{m}^{2}$ circular quadrats along each transect prior to the burn, with quadrats centered on clusters of cactus cladodes (Rebollo et al. 2002). We counted the number of live cladodes in each quadrat in January prior to the burn and recounted live cladodes in August following the burn.

We tested for differences in ANHP and plant nitrogen content on burns versus control sites for each separate burn study-year using repeated-measures analyses of variance (ANOVAs). For the burn in 2000 (with only 1 yr of ANHP measurements), we used a paried $t$ test. Results from the burns in 1998 and 2002 were analyzed in a single repeated-measures ANOVA because measurements were from the same site. To test for main effects of burning across all $5 \mathrm{yr}$ (1997-2001) of independent burn studies, we used a mixed-model ANOVA with year as a random effect (SAS 9.01).

\section{RESULTS}

For the $6 \mathrm{yr}$ in which burn studies were conducted, precipitation during April-July varied from 92 to $345 \mathrm{~mm}$ (Table 1), which is representative of long-term variation in April-July precipitation during 1969-2004 (mean $=197 \mathrm{~mm}, 1 \mathrm{SD}=$ $63 \mathrm{~mm}$, range $=92-350 \mathrm{~mm}$ ). The years of burning in our study thus encompassed dry, intermediate, and wet years. For burns in 1997, 1999, 2000, and 2001, we found no evidence that burns had any effect on ANHP in either the first or the second year following the burn (Table 2; Figs. 1A-1D). In all studies where ANHP was measured for a second year, we did detect highly significant among-year differences in ANHP 
Table 2. Results of repeated-measures ANOVAs for aboveground net herbaceous production (ANHP) for five burn studies conducted on the Pawnee National Grassland, Colorado. The year effect tests for differences in ANHP between the first postburn growing season versus the second postburn growing season. The burning $x$ year interaction tests whether burn effects differed among the $2 \mathrm{yr}$.

\begin{tabular}{clrcc}
\hline Experiment & Source & \multicolumn{1}{c}{$F$} & df & $P$ \\
\hline 1 & Burning & $<0.01$ & 1,4 & 0.987 \\
& Year & 34.99 & 1,4 & 0.004 \\
& Burning $\times$ year & 0.89 & 1,4 & 0.399 \\
2 & Burning & 4.45 & 1,6 & 0.080 \\
& Year & 186.47 & 2,5 & $<0.0001$ \\
& Burning $\times$ year & 2.01 & 2,5 & 0.228 \\
3 & Burning & 0.01 & 1,6 & 0.934 \\
& Year & 21.69 & 1,6 & 0.004 \\
& Burning $\times$ year & 0.06 & 1,6 & 0.813 \\
5 & Burning & 1.31 & 1,6 & 0.296 \\
& Burning & 0.95 & 1,6 & 0.367 \\
& Year & 105.51 & 1,6 & $<0.0001$ \\
& Burning $\times$ year & 0.86 & 1,6 & 0.390 \\
\hline
\end{tabular}

related to the variation in precipitation (Table 2; Fig. 1). For the site where a burn was conducted in 1998 and again in 2002, we found marginal evidence for a negative burn effect on ANHP (Table 2; burning main effect, $P=0.080$ ). Differences in mean ANHP for burned versus control treatments were extremely small for the first postburn growing seasons in 1998 and 2002 (Fig. 1E). Biologically meaningful differences in mean ANHP for burned versus control sites were observed only for the second growing season after the 2002 burn (19\% reduction in ANHP on burned plots; Fig. 1E).

To test whether burning had any small but consistent effects across years, we compared mean ANHP for the first postburn growing season for each of the five independent burn studies during 1997-2001 (excluding results from the repeat burn in 2002). We again found no evidence that burning had any significant main effects on total ANHP (mixed-model ANOVA; year $\times$ burning interaction: $F_{1,28}=0.23, P=0.92$; burning main effect, $F_{1,4.4}=2.74, P=0.17$; Fig. 2 ). In addition, among-year variation in the difference between mean ANHP for burned versus control plots was not correlated with variation in April-July precipitation (simple linear regression; $\left.F_{1,3}=0.42, P=0.57\right)$. Finally, for the independent burns conducted during 1997-2001, we found no evidence that the productivity of any of five plant functional groups (C3 perennial grasses, C4 perennial grasses, annual grasses, forbs, and subshrubs) varied significantly in response to burning (multiple ANOVA; $F_{4,172}=1.63, P=0.17$; Fig. 2). Burns did reduce total dead biomass (standing dead plus litter) present on the sites each August following the burn by $64-94 \%(P<0.05$ for all comparisons; Table 3).

Prescribed burning substantially increased the nitrogen content of the dominant grass, blue grama, early in the growing season for all four burn studies we sampled (19992002). These samples, which included a combination of recent plant growth and intermixed standing dead biomass remaining from the previous year, contained 1.3-2.2 times greater nitrogen content on burns compared to control sites in mid-
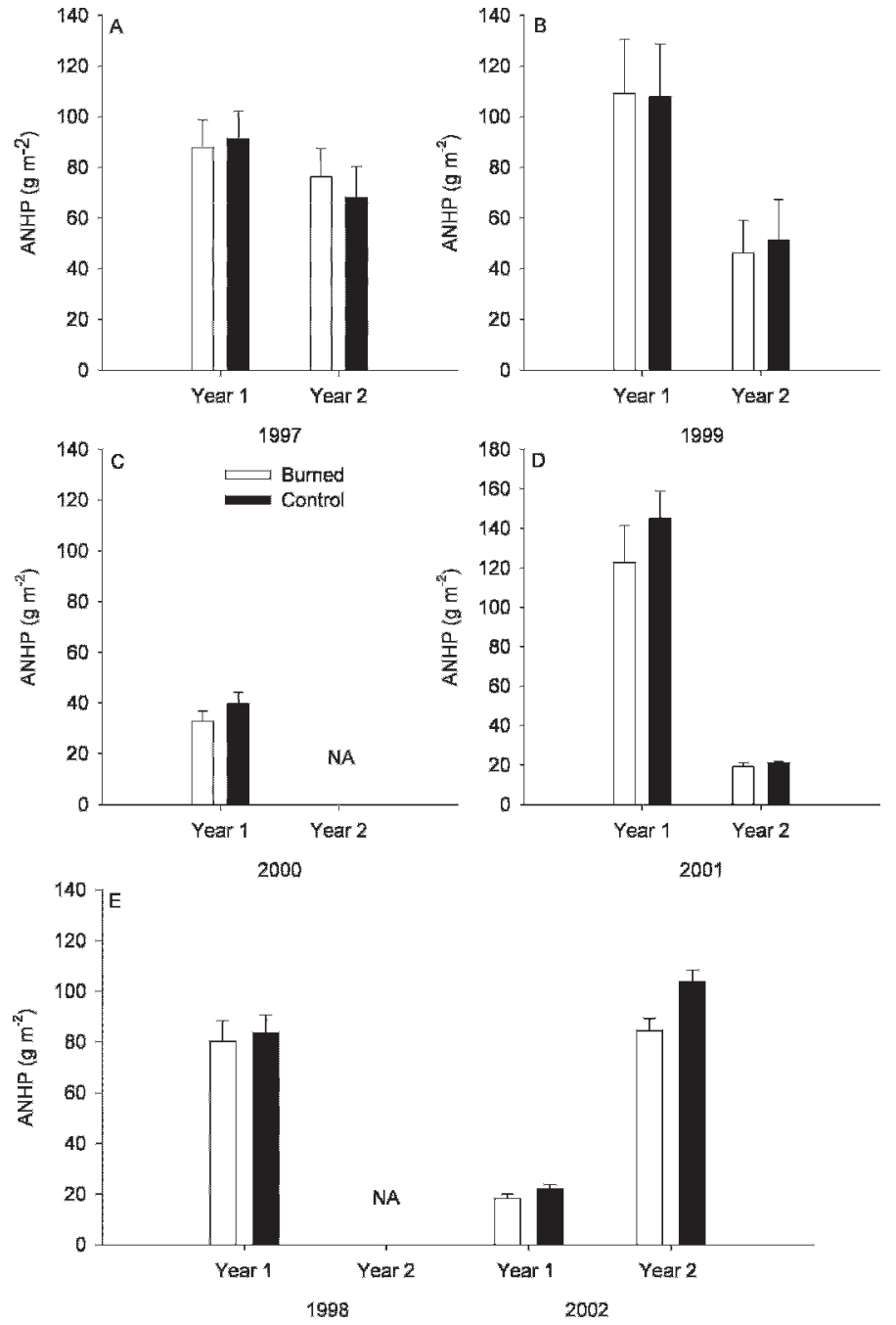

Figure 1. Aboveground net herbaceous production (ANHP) for prescribed burn studies conducted on the Pawnee National Grassland, Colorado, during 1997-2002. Year 1 and year 2 refer to the first and second growing season after each burn, and years listed beneath the panels indicate the year of the burn. Results are shown for sites burned one time (A-D) and for a site burned both in 1998 and 2002 (E). Error bars show 1 standard error for herbage production within each year and treatment.

May and 1.1-1.7 times greater nitrogen content on burns in mid-June. Nitrogen content of blue grama samples converged on burned and control sites by mid-July in the first $3 \mathrm{yr}$ (Figs. 3A-3C). In the drought of 2002, blue grama nitrogen content remained elevated on burned compared to control sites in mid-July (Fig. 3D). In 2002, we measured the nitrogen content of green blue grama biomass only, in addition to the measurement of nitrogen content for samples containing a mixture of live and dead biomass. For May, June, and July 2002 , respectively, $39 \%, 37 \%$, and $33 \%$ of the difference in nitrogen content of Bouteloua pluck samples between burns versus controls was due to differences in the nitrogen content of green biomass, while the remaining $61 \%, 63 \%$, and $66 \%$ of the difference was due to dilution by standing dead biomass on control sites. We also measured nitrogen content of the dominant forb, scarlet globemallow, which is a perennial forb that typically retains minimal standing dead biomass from the 


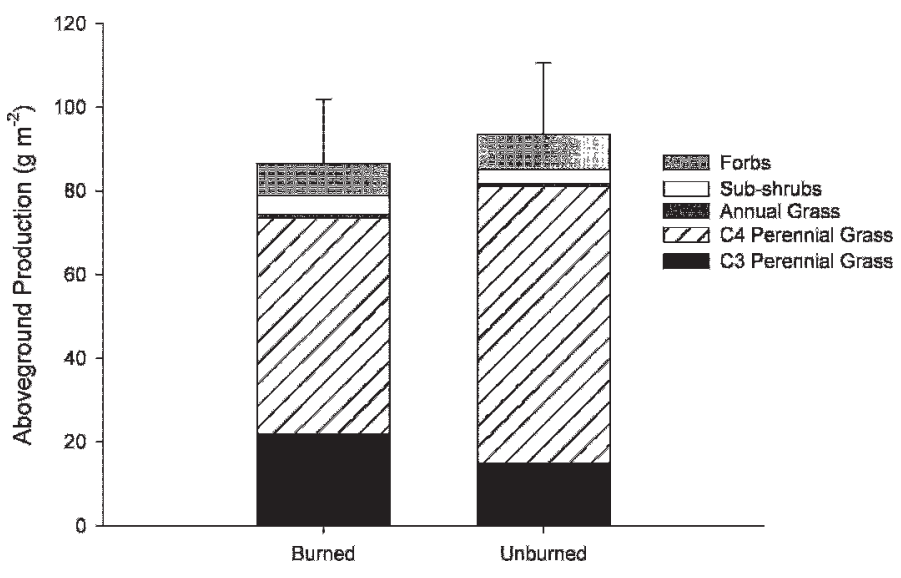

Figure 2. Production of different plant functional groups during the first postburn growing season on the Pawnee National Grassland, Colorado, averaged across all burned and unburned sites during 19972001. Error bars show 1 standard error for total aboveground net herbaceous production (ANHP) based on among-year variation.

previous year. In contrast to the results for blue grama, we found that burns had no influence on nitrogen content of scarlet globemallow during 1999-2001 (repeated-measures ANOVA: $F_{2,5}<0.83, P>0.49$ for month $\times$ burn interaction; $F_{1,6}<0.38, P>0.56$ for burn effect in all $3 \mathrm{yr}$; data not shown) and only a marginal influence in May 2002 (2.8\% nitrogen on burned sites vs. $2.2 \%$ nitrogen on control sites; $F_{2,5}=4.37$, $P=0.080)$. Finally, we found no effect of burning on nitrogen content of current-year growth of the dominant shortgrasses (blue grama and buffalograss) harvested at peak biomass in August (the ANHP quadrat samples; mean $\pm 1 \mathrm{SE}=$ $1.37 \pm 0.09 \%$ nitrogen on burns vs. $1.39 \pm 0.09 \%$ nitrogen on control sites; year $\times$ burning interaction: $F_{1,28}=0.89$, $P=0.48$; burning main effect, $F_{1,4.1}=0.08, P=0.79$ ).

We measured the effect of prescribed burning on broom snakeweed in 1998, 1999, and 2002 and on plains prickly pear cactus in 2000, 2001, and 2002 (Table 1). In 1999 (wet year), the net increase in broom snakeweed canopy volume preversus postburn was 3.2-fold greater on controls compared to burned sites (paired $t=5.77, \mathrm{df}=3, P=0.010$; Fig. 4A). In 1998, snakeweed canopy volume declined at all sites between pre- and postburn measurements (reflecting lower precipitation in 1998 compared to 1997), but the rate of decline was 2.1 times greater on burns compared to control sites (Fig. 4B). At the same site in 2002 (drought year), burning had no detectable effect on changes in snakeweed canopy volume (repeatedmeasures ANOVA, year $\times$ burning interaction: $F_{1,6}=178.9$, $P<0.001$; Fig. 4B). Low canopy volume measured in both treatments in August 2002 (postburn) reflected mortality and limited growth during the drought. In 1998, the mean mortality of broom snakeweed individuals was $30 \%$ on burned sites, with no mortality recorded at control sites. In 1999, broom snakeweed mortality rates were again greater on the burns $(12.5 \%)$ compared to control sites $(2.5 \%)$. During the drought in 2002 , mortality rates increased both on burned sites $(41.1 \%)$ and unburned sites $(22.5 \%)$. Burning also consistently reduced the density of prickly pear cactus cladodes in all $3 \mathrm{yr}$ of measurements. In 2000, cladode density declined at all sites between pre- and postburn measurements (reflecting lower
Table 3. Litter and standing dead biomass $\left(\mathrm{g} \cdot \mathrm{m}^{-2}\right)$ on burned versus control sites during the first postburn growing season in shortgrass steppe on the Pawnee National Grassland, Colorado. Values in parentheses are $1 \mathrm{SE}$.

\begin{tabular}{lrrrrr}
\hline & \multicolumn{2}{c}{ Litter } & & \multicolumn{2}{c}{ Standing dead } \\
\cline { 2 - 3 } \cline { 6 - 6 } & \multicolumn{1}{c}{ Burn } & Control & & Burn & \multicolumn{1}{c}{ Control } \\
\hline 1998 & $7.2(0.1)$ & $33.6(1.6)$ & & $4.6(0.4)$ & $7.1(0.4)$ \\
1999 & $6.3(2.1)$ & $23.2(6.9)$ & & $1.6(1.2)$ & $7.6(2.4)$ \\
2000 & $5.4(0.7)$ & $85.5(3.9)$ & & $0.7(0.1)$ & $31.4(1.4)$ \\
2001 & $15.5(0.8)$ & $50.0(4.0)$ & & $0.6(0.1)$ & $4.8(0.5)$ \\
2002 & $19.7(1.8)$ & $42.8(1.8)$ & & $1.2(0.3)$ & $15.1(1.5)$ \\
\hline
\end{tabular}

precipitation in 2000 compared to 1999) but declined at more than double the rate on burns compared to controls (paired $t=2.85, \mathrm{df}=3, P=0.065$; Fig. 5A). In 2001, cladode density increased at all sites pre- versus postburn, but the rate of increase was four times greater on controls compared to burns (paired $t=5.20, \mathrm{df}=3, P=0.014$; Fig. 5B). In 2002, cladode density increased by $50 \%$ on controls and declined by $50 \%$ on burns (paired $t=4.68, \mathrm{df}=3, P=0.018$; Fig. 5C).

\section{DISCUSSION}

Effects of fire on herbaceous plant production in shortgrass steppe can vary from strongly negative during the first one to two postburn growing seasons (e.g., Hopkins et al. 1948; Dwyer and Pieper 1967; Brockway et al. 2002) to neutral or positive (Heirman and Wright 1973; Wright 1974). Factors underlying such variability may include the timing and intensity of fires and/or the amount of precipitation received during the first postfire growing season (Wright and Bailey 1982; Ford 1999; Engle and Bidwell 2001). Fire intensity appears to be a particularly important determinant of the effects on plant production in shortgrass steppe. First, large negative effects have resulted from growing-season burns in areas not grazed by large herbivores (Brockway et al. 2002; Ford and Johnson 2006). Second, early spring burns often have reduced effects compared to growing-season burns but still can have significant negative effects when conducted in ungrazed or lightly grazed sites (Launchbaugh 1964; Trlica and Schuster 1969; Brockway et al. 2002; Ford and Johnson 2006). For example, the burns studied by Brockway et al. (2002) were in ungrazed shortgrass steppe with mean annual precipitation of $400 \mathrm{~mm}$ and an average fuel load (aboveground standing material plus litter) of $345 \mathrm{~g} \cdot \mathrm{m}^{-2}$. Early-spring (dormant season) burns at this site reduced aboveground production by $33 \%$ during the first postburn growing season (Brockway et al. 2002). In our study area with mean annual precipitation of only $344 \mathrm{~mm}$, cattle were present at moderate stocking rates during the growing season both prior to and after burns. Although we did not measure fuel loads prior to the burns, our August measurements of aboveground biomass including litter across all unburned sites during 1998-2002 (Fig. 1; Table 3) averaged only $111 \mathrm{~g} \cdot \mathrm{m}^{-2}$ after assuming that $40 \%$ of current-year production is removed by cattle, with a maximum value of $142 \mathrm{~g} \cdot \mathrm{m}^{-2}$ in 2001. Given that some aboveground biomass would be lost to native herbivores, wind, and decomposition by 

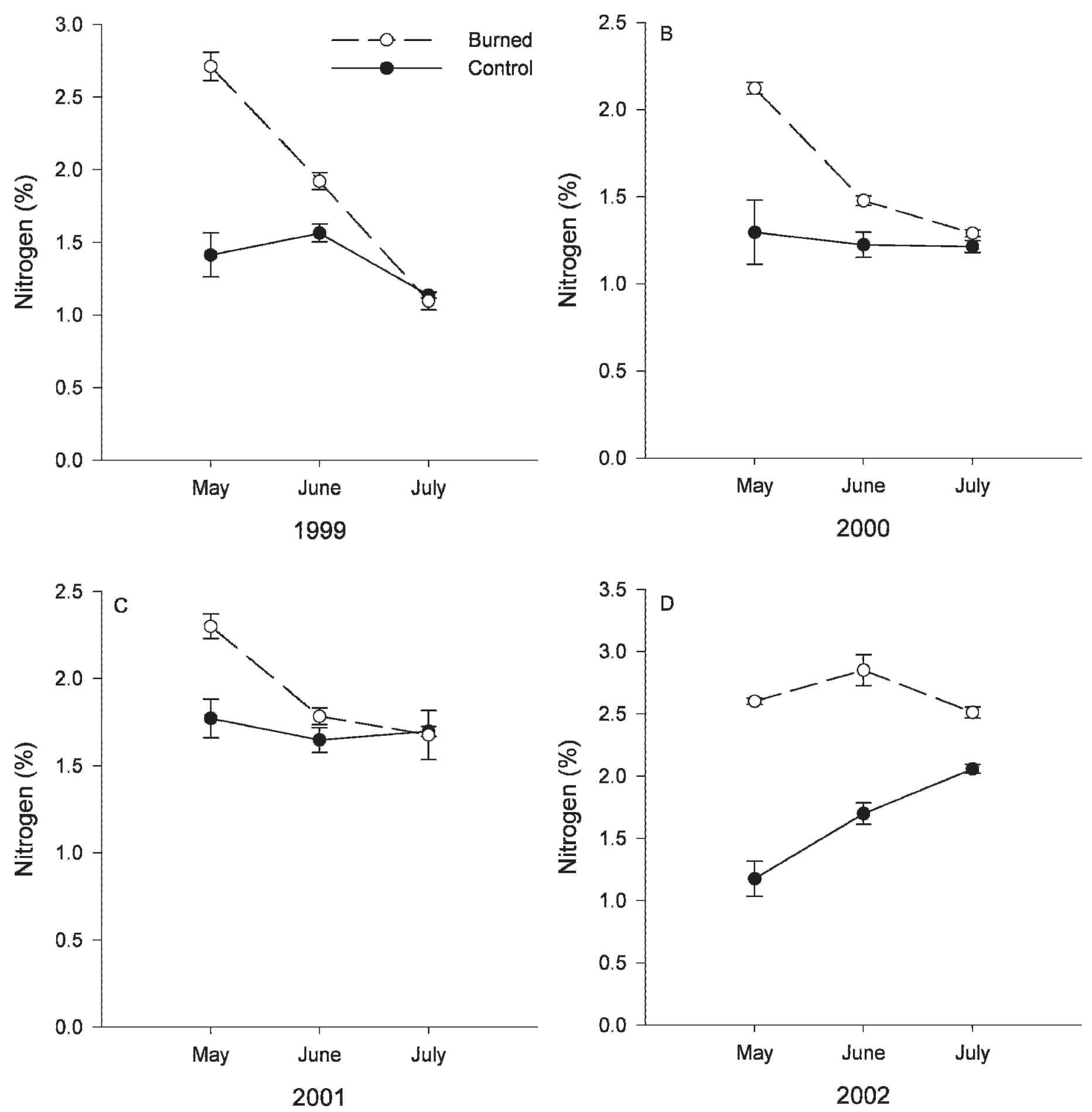

Figure 3. Effects of prescribed burns on the Pawnee National Grassland, Colorado, on nitrogen content of aboveground Bouteloua gracilis biomass during May-July of the first postburn growing season.

the following March, these values indicate that the burns we studied had substantially lower fuel loads than earlier studies in more productive shortgrass sites that were ungrazed or only lightly grazed. Our findings indicate that under most weather conditions, late-winter burns conducted in previously grazed shortgrass steppe do not negatively affect plant production.

Our results for burn effects on plant production were consistent across the wide range of growing-season precipitation conditions that can occur in shortgrass steppe, with one exception. The burn in 2002 was followed by a severe drought, with only $92 \mathrm{~mm}$ of precipitation during April-July. Under these conditions, burning had no effect on production during the drought (2002) but did reduce mean herbaceous production by $19 \%$ during the postdrought (2003) growing season. One potential explanation is that the combination of burning followed by drought increased evaporative soil moisture loss and grass crown mortality compared to drought alone such that effects were not apparent until the second growing season. 

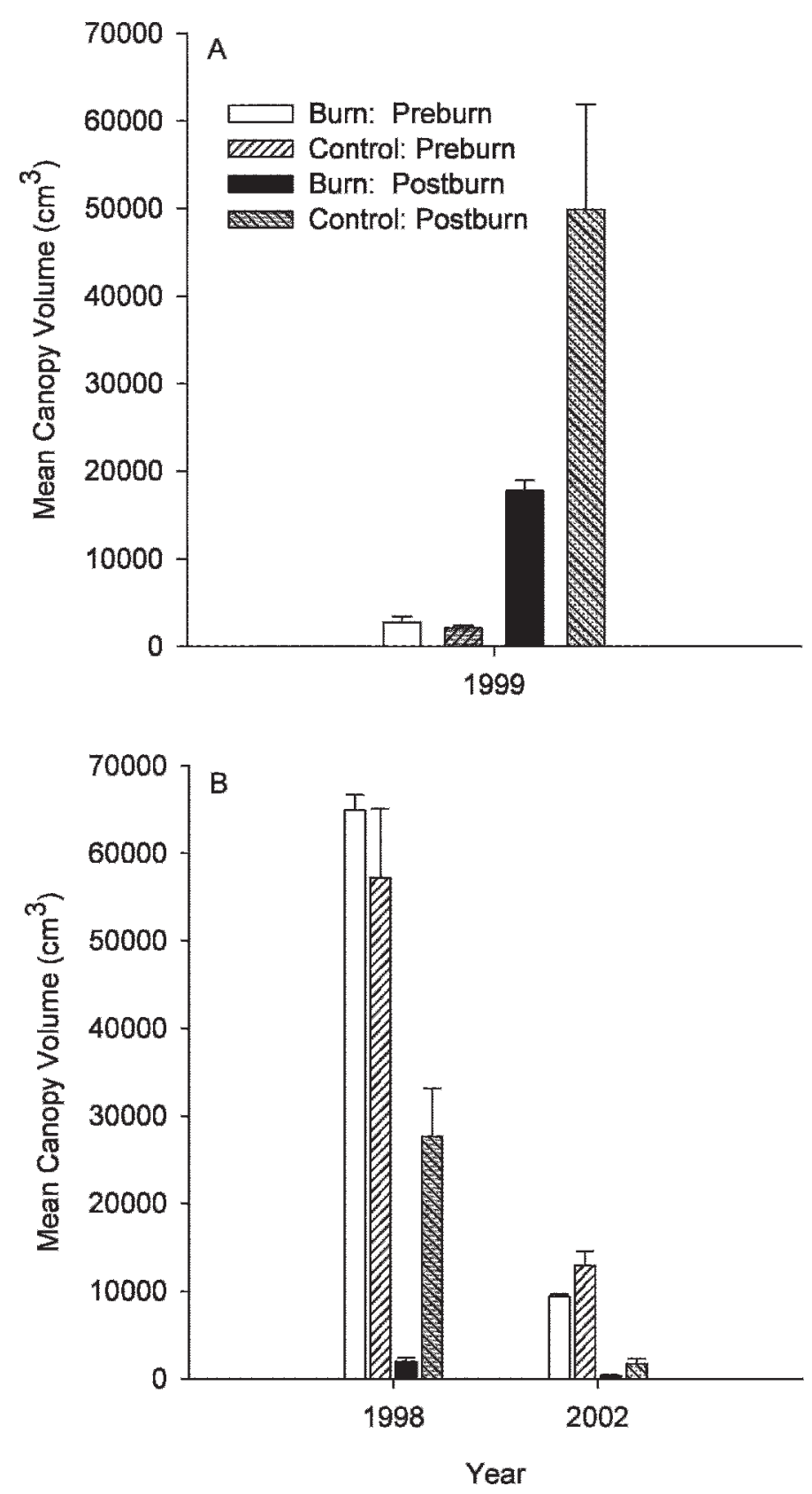

Figure 4. Effects of prescribed burns conducted in 1999 (A) and at a site burned both in 1998 and in 2002 (B) on broom snakeweed canopy volume on the Pawnee National Grassland, Colorado.

However, this site was burned in both 1998 and 2002, so we cannot distinguish between the potential influence of repeated burning versus the drought. Long-term studies examining the effects of different fire frequencies in shortgrass steppe would be of value in addressing this question. Despite the combination of a repeat burn followed by a severe drought, burn effects on ANHP were small compared to interannual fluctuations in ANHP due to precipitation patterns.

The scope of inference from a single burn in a single year is limited because of the lack of treatment replication. However, we replicated burn versus control comparisons both in time (independent measurements over five different years) and spatially in 1999 (burns in four independent allotments), with consistent results in all comparisons except the 2002 drought.
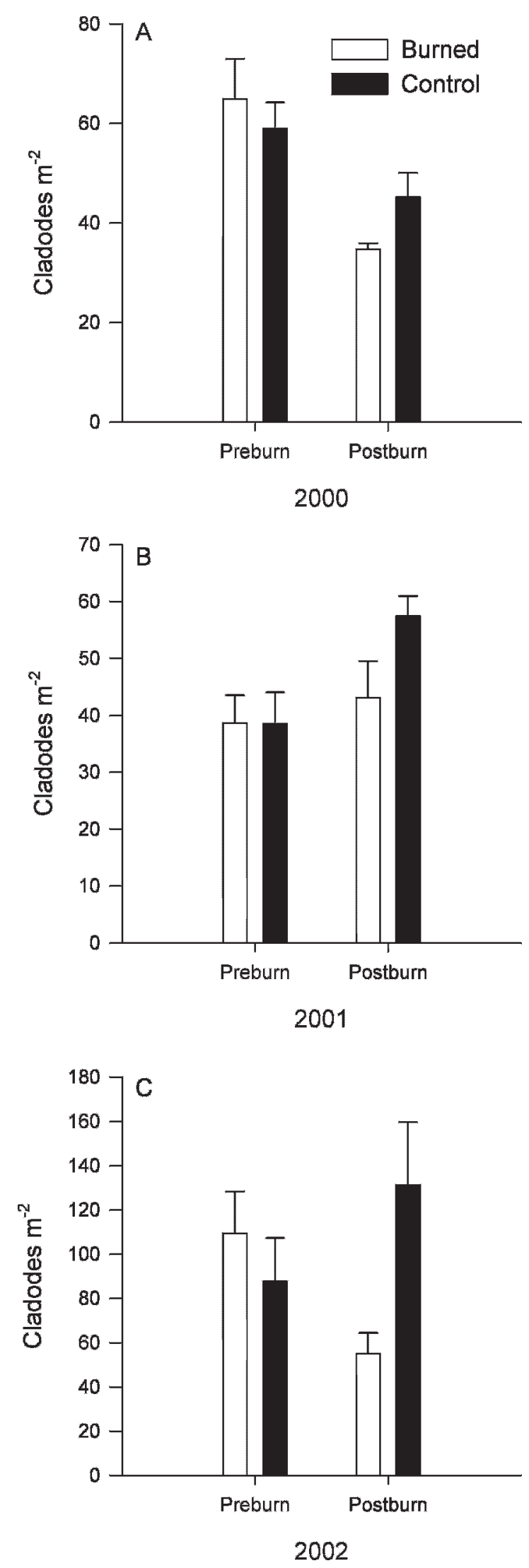

Figure 5. Effects of prescribed burns conducted during 2000-2002 on changes in the abundance of live cladodes of Opuntia polyacantha in quadrats centered over clusters of cacti cladodes (see "Methods" section) on the Pawnee National Grassland, Colorado. 
Overall, our results, combined with findings from earlier studies, support the hypothesis that seasonality and intensity of burning are key determinants of the effect on plant productivity. Furthermore, the lack of a grazing effect at moderate stocking rates during the first postburn growing season is counter to common perceptions of a need for deferment of grazing after burning in arid regions. We did observe reduced productivity on the burn followed by the 2002 drought, consistent with the idea that burn effects depend on postburn moisture availability. However, the magnitude of variation in burn effects across the precipitation conditions in our study was small compared to the differences between growing-season versus dormant-season burns (results of this study and Brockway et al. 2002), again emphasizing the more important role of burn seasonality and intensity.

In mixed and tallgrass prairies, burning can influence the distribution and performance of ruminant herbivores by removing standing dead material and enhancing forage quality (Coppedge and Shaw 1998; Knapp et al. 1999; Fuhlendorf and Engle 2004; Vermiere et al. 2004). Less is known about such interactions in shortgrass steppe, where summer forage quantity may be comparatively more important for ruminant herbivores than forage quality (Hobbs and Swift 1988). We found that prescribed burns substantially increased the nitrogen content of blue grama biomass early in the growing season, with burn and control nitrogen content converging by mid-July. Where cattle are given free selection between burned and unburned areas early in the growing season, these results suggest the potential for burns to enhance cattle performance to the extent that forage quantity is not limiting during the grazing season. While cattle responses to burns were not evaluated in our study, Heirman and Wright (1973) documented increased cattle use of burned compared to unburned sites dominated by tobosa (Hilaria mutica) and buffalograss at the southern edge of the shortgrass steppe. Burn effects on blue grama nitrogen content appear to be due primarily to removal of low-nitrogen standing dead biomass by burning; nitrogen content of the dominant forb, which retains minimal dead material from previous growing seasons, was unaffected by burning. Our measurements of blue grama in 2002 also indicated that most of the increased $\mathrm{N}$ content of blue grama on burns was due to the removal of standing dead biomass.

Shortgrass steppe is dominated by blue grama, but some uncommon plant species are notable because they both are unpalatable to livestock and create small-scale structural heterogeneity that can influence native arthropod and vertebrate communities. Broom snakeweed is an unpalatable, perennial subshrub that can be toxic to livestock and suppress growth of preferred forage. McDaniel et al. (1997) found that prescribed fire can be used to control infestations of broom snakeweed but noted several limitations and trade-offs concerning burn implementation. Summer burns induced greater snakeweed mortality than spring burns, but summer burn implementation depended on the convergence of ideal weather conditions (McDaniel et al. 1997). Summer burns also facilitated establishment of snakeweed seedlings, while early-spring burns did not (McDaniel et al. 2000). Conditions for prescribed fire may be more predictable during the winter-spring transition, while the effects on both broom snakeweed (McDaniel et al. 1997) and forage production (Brockway et al. 2002) may be reduced because only dormant tissues are consumed, burn temperatures are lower, and snakeweed canopies are only partially charred. Indeed, while we found that late-winter burns on the Pawnee National Grassland substantially reduced mean canopy volume of broom snakeweed, the mortality rates we recorded on burns $(12-41 \%)$ were still lower than mortality rates on early spring $(65 \%)$ and summer burns $(92 \%)$ in ungrazed New Mexico shortgrass steppe (McDaniel et al. 1997). Our findings indicate that dormant-season burns temporarily reduce the abundance and size of broom snakeweed in grazed shortgrass steppe but that a majority of individuals survive, which may quickly allow snakeweed populations to recover.

Prickly pear cactus is one of the most abundant nongrass species in shortgrass steppe (Milchunas et al. 1989) and can significantly reduce forage consumption by cattle because of the refuge effect created by spines (Bement 1968; Rebollo et al. 2002). Treatments such as heavy grazing and prescribed burning are often perceived to enhance cactus growth because they remove standing dead vegetation and increase the visibility of new cladode growth (Bement 1968). However, we found that burns caused a small but significant reduction in cactus abundance, which could enhance accessibility of forage to cattle for one to two growing seasons after the burn. In more productive grasslands in central Texas with hotter burns, prescribed fire can induce considerably greater prickly pear mortality, with summer fires having stronger effects than winter fires (Ansley and Castellano 2007). These differences may be due to negative effects of greater fire intensity on the insulating wax coating of cladodes. Over longer time scales, variability in precipitation and insect outbreaks may cause more substantial fluctuations in cactus abundance in shortgrass steppe (Houston 1963; Bement 1968) than low-intensity prescribed burns.

Species such as cactus and broom snakeweed can also be an important source of small-scale vegetation structure in shortgrass steppe, which in turn can affect bird communities and, to a lesser extent, small mammal communities (Milchunas et al. 1998). Documented burn effects on broom snakeweed and cactus, combined with the removal of fine fuels, are consistent with habitat requirements of the mountain plover (Knopf and Miller 1994) and McCown's longspur (Calcarius mccownii; Sedgwick 2004). Conversely, removal of dead biomass and taller vegetation could temporarily reduce use of burned sites by birds such as lark bunting (Calamospiza melanocorys) and small mammals such as hispid pocket mice (Chaetodipus hispidus) and western harvest mice (Reithrodontomys megalotis; Milchunas et al. 1998; Stapp et al. 2008).

\section{IMPLICATIONS}

Prescribed fire has increasingly been considered as a means to restore shortgrass disturbance processes (Brockway et al. 2002), enhance wildlife habitat (Svingen and Giesen 1999; Augustine et al. 2007; Thompson et al. 2008), and control unpalatable plant species (McDaniel et al. 1997). Potential trade-offs for forage production are unclear because previous studies have been conducted primarily in ungrazed conditions. Our results indicate that late-winter burns in moderately grazed shortgrass steppe do not negatively affect herbaceous production under most conditions and have a small negative effect on production following severe drought. Furthermore, burns can temporarily 
suppress the abundance of broom snakeweed and prickly pear cactus while enhancing forage nitrogen content early in the growing season. Negative effects on prickly pear can increase forage available to livestock independent of the burning effect on total herbaceous production (Bement 1968). These findings suggest that prescribed burns conducted in shortgrass steppe for objectives unrelated to livestock production can also have neutral or positive consequences for livestock.

\section{ACKNOWLEDGMENTS}

We thank Mark Lindquist, Nicole Kaplan, Judy Hendryx, and the LTER field crew for assistance with data collection and lab analyses; the Crow Valley Livestock Cooperative for providing the cattle at the study sites; and Randy Reichert for providing allotment stocking rates. We thank Justin Derner, Alan Knapp, Jack Cully, and an anonymous reviewer for helpful comments of this article and Mark West for statistical advice.

\section{LITERATURE CITED}

Ansley, R. J., and M. J. Castellano. 2007. Prickly pear cactus responses to summer and winter fires. Rangeland Ecology \& Management 60:244-252.

Augustine, D. J., J. F. Cully, and T. L. Johnson. 2007. Influence of fire on blacktailed prairie dog colony expansion in shortgrass steppe. Rangeland Ecology \& Management 60:538-542.

Bement, R. E. 1968. Plains pricklypear: relation to grazing intensity and blue grama yield on central Great Plains. Journal of Range Management 21:83-86.

Brockway, D. G., R. G. Gatewood, and R. B. Paris. 2002. Restoring fire as an ecological process in shortgrass prairie ecosystems: initial effects of prescribed burning during the dormant and growing seasons. Journal of Environmental Management 65:135-152.

Coluins, S. L., AND M. D. Smith. 2006. Scale-dependent interaction of fire and grazing on community heterogeneity in tallgrass prairie. Ecology 87:2058-2067.

Coppedge, B. R., AND J. H. Shaw. 1998. Bison grazing patterns on seasonally burned tallgrass prairie. Journal of Range Management 51:258-264.

Dwyer, D. D., ANd R. D. Pieper. 1967. Fire effects on blue grama-pinyon-juniper rangeland in New Mexico. Journal of Range Management 20:359-362.

Engle, D. M., And T. G. Bidwell. 2001. Viewpoint: the response of central North American prairies to seasonal fire. Journal of Range Management 54:2-10.

Erichsen-Arychuk, C., E. W. Bork, and A. W. Balley. 2002. Northern dry mixed prairie responses to summer wildfire and drought. Journal of Range Management $55: 164-170$.

Ford, P. L. 1999. Response of buffalograss (Buchloe dactyloides) and blue grama (Bouteloua gracilis) to fire. Great Plains Research 9:261-276.

Ford, P. L., AND G. V. Johnson. 2006. Effects of dormant- vs. growing-season fire in shortgrass steppe: biological soil crust and perennial grass responses. Journal of Arid Environments 67:1-14.

Fuhlendorf, S. D., And D. M. Engle. 2004. Application of the fire-grazing interaction to restore a shifting mosaic on tallgrass prairie. Journal of Applied Ecology 41:604-614.

Heirman, A. L., and H. A. Wright. 1973. Fire in medium fuels of West Texas. Journal of Range Management 26:331-335.

HobBS, N. T., AND D. M. Swift. 1988. Grazing in herds: when are nutritional benefits realized? American Naturalist 131:760-764.

Hopkins, H., F. W. Albertson, and A. Riegel. 1948. Some effects of burning upon a prairie in west-central Kansas. Transactions of the Kansas Academy of Science 51:131-141.

Houston, W. R. 1963. Plains pricklypear, weather, and grazing in the Northern Great Plains. Ecology 44:569-574.

Knapp, A. K., J. M. Blair, J. M. Briggs, S. L. Collins, D. C. Hartnett, L. C. Johnson, AND E. G. Towne. 1999. The keystone role of bison in North American tallgrass prairie. BioScience 49:39-50.
Knopf, F. L., And B. J. Miller. 1994. Charadrius montanus-montane, grassland, or bare-ground plover? The Auk 111:504-506.

Knopf, F. L., And M. B. Wunder. 2006. Mountain plover (Charadrius montanus). In: A. Poole [ED.]. The birds of North America online. Ithaca, NY, USA: Cornell Laboratory of Ornithology. Available at: http://bna.birds.cornell.edu/BNA/ Login.do. Accessed 5 June 2007.

Lauenroth, W. K., and D. G. Milchunas. 1992. Short-grass steppe. In: R. Coupland [ED.]. Ecosystems of the world. New York, NY, USA: Elsevier. p. 183-226.

Launchbaugh, J. L. 1964. Effects of early spring burning on yields of native vegetation. Journal of Range Management 17:5-6.

McDaniel, K. C., D. B. Carroll, and C. R. Hart. 2000. Broom snakeweed establishment following fire and herbicide treatments. Journal of Range Management 53:239-245.

McDaniel, K. C., C. R. Hart, and D. B. Carroll. 1997. Broom snakeweed control with fire on New Mexico blue grama rangeland. Journal of Range Management 50:652-659.

Milchunas, D. G., J. R. Forwood, and W. K. Lauenroth. 1994. Forage production across fifty years of grazing intensity treatments in shortgrass steppe. Journal of Range Management 47:133-139.

Milchunas, D. G., and W. K. Lauenroth. 1992. Carbon dynamics and estimates of primary production by harvest, $\mathrm{C}^{14}$ dilution, and $\mathrm{C}^{14}$ turnover. Ecology 73 : 593-607.

Milchunas, D. G., W. K. LauRenroth, and I. C. Burke. 1998. Livestock grazing: animal and plant biodiversity of shortgrass steppe and the relationship to ecosystem function. Oikos 83:65-74.

Milchunas, D. G., W. K. Lauenroth, I. C. Burke, and J. K. Detling. 2008. Effects of grazing on vegetation. In: W. K. Lauenroth and I. C. Burke [EDS.]. Ecology of the shortgrass steppe: perspectives from long-term research. New York, NY, USA: Oxford University Press. p. 389-446.

Milchunas, D. G., W. K. Lauenroth, P. L. Chapman, and M. K. Kazempour. 1989. Effects of grazing, topography and precipitation on the structure of a semiarid grassland. Vegetatio 80:11-23.

Rebollo, S., D. G. Milchunas, and I. Noy-Meir. 2005. Refuge effects of a cactus in grazed shortgrass steppe. Journal of Vegetation Science 16:85-92.

Rebollo, S., D. G. Milchunas, I. Noy-Meir, and P. L. Chapman. 2002. The role of a spiny plant refuge in structuring grazed shortgrass steppe plant communities. Oikos 98:53-64.

Sala, O., and W. K. Lauenroth. 1982. Small rainfall events: an ecological role in semiarid regions. Oecologia 53:301-304.

Sedgwick, J. A. 2004. McCown's longspur (Calcarius mccownil): a technical conservation assessment. USDA Forest Service, Rocky Mountain Region. Available at: http://www.fs.fed.us/r2/projects/scp/assessments/mccownslongspur. pdf. Accessed 26 November 2008.

Stapp, P., B. Van Horne, and M. D. Lindquist. 2008. Ecology of mammals of the shortgrass steppe. In: W. K. Lauenroth and I. C. Burke [EDS.]. Ecology of the shortgrass steppe: perspectives from long-term research. New York, NY, USA: Oxford University Press. p. 132-180.

Svingen, D., And K. GIeSEn. 1999. Mountain plover (Charadrius montanus) response to prescribed burns on the Comanche National Grassland. Journal of the Colorado Field Ornithologists 33:208-212.

Thompson, C. M., D. J. Augustine, and D. M. Mayers. 2008. Swift fox response to prescribed fire in shortgrass steppe. Western North American Naturalist 68:251-256.

Trlica, M. J., And J. L. Schuster. 1969. Effects of fire on grasses of the Texas high plains. Journal of Range Management 22:329-333.

Vermiere, L. T., R. B. Mitchell, and S. D. Fuhlendorf. 2001. Sand sagebrush response to fall and spring prescribed burns. In: Shrubland ecosystem genetics and biodiversity: proceedings. USDA-Forest Service, Proceedings RMRS-P-21. p. 233-235.

Vermeire, L. T., R. B. Mitchell, S. D. Fuhlendorf, and R. L. Gillen. 2004. Patch burning effects on grazing distribution. Journal of Range Management 57:248-252.

WriGHt, H. A. 1974. Effect of fire on southern mixed prairie grasses. Journal of Range Management 27:417-419.

Wright, H. A., AND A. W. Balley. 1982. Fire ecology: United States and southern Canada. New York, NY, USA: John Wiley and Sons. 501 p. 